\title{
LA SECCIÓN DE SOCIEDAD EN LOS INFORMATIVOS DE TELEVISIÓN
}

\section{SOCIETY SECTION EN TV NEWS}

\author{
AUTOR \\ Manuel Gutiérrez \\ Universidad Complutense de Madrid (España). \\ mtgutierrez@hotmail.com
}

\section{RESUMEN}

En los medios audiovisuales, las secciones no están tan delimitadas como en la prensa escrita, por eso, Sociedad es una especie de cajón desastre donde caben temas de muy diversa índole pero sobre todo sucesos: asesinatos, detenciones, narcotráfico, pederastia, accidentes, incendios, desastres naturales .... Pero también sanidad, educación o medio ambiente, si bien es cierto, que los primeros dominan sobre los segundos, hasta el punto de que la sección de Sociedad es denominada entre el resto de compañeros de redacción como la sección de "Suciedad", en una clara alusión a la batería de sucesos que recoge y al morbo, con el que por otra parte, se tratan.

\section{PALABRAS CLAVE}

Televisión - Sociedad - Sucesos - Educación - Sanidad - Periodismo 


\section{ABSTRACT}

In the media, the sections are not as defined as in newspapers, therefore, Society is a ragbag with many diverse topics but mainly events or incidents: assassinations, arrests, drug trafficking, child abuse, accidents, fires, natural disasters .... But also health, education or environment, whether it is true that the former dominate over the second, this is why the professionals called "Dirt" (in spanish, both words are very similar: Sociedad/Suciedad), in a clear allusion a battery of morbid events that deals.

\section{KEY WORDS}

Television - Society - Events - Education - Health - Journalism

\section{ÍNDICE}

1. Introducción

2. Agenda Setting

3. El poder de las imágenes

4. El lenguaje televisivo en las noticias de Sociedad

5. Conclusiones

\section{Introducción}

En radio y televisión, las secciones no están tan delimitadas como en la prensa. Este hecho tiene especial relevancia en la sección de Sociedad que se convierte así en un cajón desastre donde tienen cabida temas de muy diversa índole: desde los sucesos (asesinatos, detenciones, narcotráfico, pederastia, accidentes, incendios, desastres 
naturales) hasta sanidad, educación o medio ambiente. En el caso de la televisión, medio en el que se centra este artículo, es evidente que dominan los primeros, sucesos, sobre los demás, hasta el punto de que la sección de Sociedad es denominada entre los propios compañeros de redacción como la sección de Suciedad, en una clara alusión a la batería de sucesos que recoge y al morbo con el que, por otra parte, se tratan.

¿Y por qué las noticias de Sociedad en televisión se tratan con ese exceso de morbo? Ya lo decía Furio Colomo a finales de los 70: hay un vínculo entre la información televisada y la mala noticia (Colomo, 1976: 52). Cuanto más trágica sea una noticia, más verdadera resulta a los ojos del telespectador. En televisión, preponderan las noticias escabrosas, las noticias que reflejan lo peor de la sociedad. Y... ¿por qué? Por una sencilla pero maquiavélica razón: para captar la atención de la audiencia. La realidad como espectáculo o lo que se ha dado en llamar el infoentretenimiento.

¿Por qué los avances sobre una vacuna contra la malaria desarrollados por científicos españoles interesa menos que un incendio espectacular con el resultado de dos muertos? ¿Por la proximidad? ¿Por las circunstancias que rodean al hecho? ¿Por la disponibilidad de imágenes? Lo cierto es que el descubrimiento de la vacuna puede salvar la vida de un millón de personas al año. Los diarios informan sobre este importante avance pero pocas televisiones lo cuentan. ¿No dan importancia a lo importante?

En televisión no se informa, se cuenta. Además, se muestran imágenes relacionadas con los hechos y se incluyen testimonios directos de los protagonistas y testigos, a ser posible en los momentos de mayor emoción o sufrimiento; si hay lágrimas, sollozos, crispación... ¡mejor! Todo ello hace que las noticias sean más impactantes, capten la atención de la audiencia, sorprendan. Lo esperpéntico, lo marginal o lo provocativo embelesa a la audiencia, vende mucho más que una argumentación, un análisis o un dato riguroso. Se trata de teatralizar, de dramatizar, de crear 
espectáculo, exaltar lo accidental a través del espectáculo, ante el tedio de lo cotidiano, poco televiso, lo marginal, lo escandaloso.

Basta un par de ejemplos para comprobarlo: hace meses, un octogenario mataba a su hijo en Vicálvaro (Madrid). Les pedí a mis alumnos que analizaran los diferentes tratamientos que hacían la prensa escrita y la televisión. La primera se limitaba a informar de los hechos y las posibles causas; la televisión se centraba en los detalles que, junto a las imágenes de la casa, las declaraciones de los vecinos o el furgón que trasladaba el cuerpo convertían la noticia en el argumento de una película de terror.

Algo similar ocurre con el balance de tráfico después de un fin de semana. No es lo mismo leer que han muerto 10 personas menos respecto al año anterior que oir la misma información mientras se ven imágenes de cadáveres cubiertos en el arcén, ambulancias o coches destrozados. Esto es más impactante.

Las noticias de Sociedad en televisión no se conciben tanto como una explicación de los hechos sino como una síntesis impactante para los sentidos (Nebreda y otros, 1985). La duración de la noticia no depende de la importancia sino de la capacidad de las imágenes para despertar la atención. Se busca la espectacularización expositiva. Por ejemplo, en el caso de los accidentes de carretera, hasta hace poco, no se explicaban las causas. Los informativos se limitaban a dar el número de muertos y a sacar imágenes del accidente más espectacular. Desde que el Gobierno fue consciente del problema, este tipo de información recibe un tratamiento diferente en los medios: hoy conocemos el número de muertos, pero también las causas: tramos peligrosos en carreteras secundarias, conductores con altas tasas de alcohol, exceso de velocidad. Informar no es sólo narrar lo que pasa, sino también ahondar en las causas y muchas veces, por falta de tiempo, esto no se hace. 


\section{Agenda Setting}

Es cierto que la actualidad nos impone asuntos que van impactando en la sociedad hasta crear verdaderos de estados de ánimo hasta el punto de que las instituciones impulsan nuevas iniciativas para solucionarlos. Los casos de pederastas o los problemas de saturación que tiene la justicia son un ejemplo de ello.

El problema es que también se crean estado de psicosis o de alarma que pudren la convivencia social (Contreras y Palacio, 2001). Aquí es obligada una referencia a la agenda Setting que forma parte de la teoría sobre los efectos sociales de los medios de comunicación. Los ciudadanos llegan a formarse un juicio personal acerca de lo que es importante en la vida pública en función de lo que informen los medios.

Cuanto más se hable de un asunto, más importancia colectiva tendrá. Y la actualidad nos proporciona sobrados ejemplos de que esto es así: niños atacados violentamente por perros o casos de violencia escolar donde algunos profesores eran agredidos por alumnos. Se llega a publicar y emitir tanto de ello, que parece que todos los perros muerden o que todos los escolares acosan a sus profesores. De repente, esos temas dejan de interesar o son sustituidos por otros y parece que los violentos -perros y escolares- han desaparecido del mapa.

El $80 \%$ de las noticias que llegan a los periódicos no se publican. Sería interesante analizar cuáles y por qué. Y sobre todo, qué criterios realmente rigen a la hora de seleccionar noticias en cada medio. Está claro que la agenda Setting tiene mucho que ver en ello.

Las noticias de Sociedad en televisión suelen ser las más numerosas pero no las más importantes (De Aguilera, 1985: 196-197). Aparecen en la segunda parte de un informativo, antes de cultura y deportes. Generalmente, con las noticias de Sociedad, el editor busca templar la balanza en los ánimos del espectador que puede 
encontrarse crispado y que, sin embargo, debe aguantar hasta el final del informativo. Si las noticias de los primeros bloques, política o economía, han sido duras, espesas, o profundas, se elegirán noticias sociales poco relevantes o de tintes relajados, muchas de ellas basadas en encuestas y sondeos de firmas que buscan publicidad y que han llegado a la redacción en forma de videocomunicados: los españoles eligen a la actriz más sexy, patrocinado por una revista de cine; el uso de la falda por las mujeres españolas, facilitado por una conocida marca de compresas; los efectos positivos de los videojuegos según una empresa que los crea; el consumo de helados al llegar el verano; etc. Son noticias poco relevantes que suelen entrar a formar parte de la "nevera". Si hay tiempo, se emiten. Si no, como son atemporales, se guardan para otro día, generalmente el fin de semana.

Por el contrario, si el informativo ha contado con escasos o ligeros temas de actualidad política o nacional, en la sección de Sociedad veremos noticias más relevantes, adelantos médicos en sanidad, campañas de tráfico, el estado de la educación, etc.

\section{El poder de las imágenes}

En uno u otro caso, informar en televisión, ya sean noticias de Sociedad, de Economía o de Cultura, resulta difícil. Se trata de escribir bien, en un tiempo limitado y además, en función de la imagen. El periodista en televisión tiene que combinar dos tipos de narración, la verbal y la visual (Roglán y otros, 1996: 86). La imagen debe corresponder con la palabra, en caso contrario, podemos confundir al telespectador en el que siempre va a predominar la vista sobre el oído.

De lo que no cabe duda es que la disponibilidad de imágenes es un factor fundamental en televisión. Las informaciones poco interesantes con imágenes tienen más ventaja sobre las interesantes sin imágenes. 
Pero una imagen no vale más que mil palabras. No en la mayoría de los casos. Suelo pedir a mis alumnos que realicen una sencilla práctica ante un informativo televisado: les pido que bajen el volumen de una noticia y traten de entender lo que les cuentan las imágenes. Es una tarea ardua que algunas cadenas facilitan incorporando, cada vez más, rótulos o gráficos. Lo cual corrobora que, no nos engañemos, la palabra sigue siendo el mejor instrumento para expresar los pensamientos. La imagen es eficaz para mostrar Cómo son las cosas, o parte de las cosas, pero en todo caso, no explica POR QUÉ son así.

La imagen informativa ha de obedecer a criterios de verdad, autenticidad y vinculación a la realidad originaria. Las imágenes son un espejo de la realidad, o al menos, una representación icónica de la realidad (Barroso, 1992: 167). Marcan y limitan la narración informativa y obligan a los periodistas a escribir de una manera determinada porque las imágenes son la base del éxito de la televisión, lo que la gente recuerda después de haber recibido una noticia. La fuerza de la imagen, al imponerse sobre la palabra, distorsiona el mensaje final de la información.

La ventaja del periodismo televisivo, frente a cualquier otro medio de comunicación, es que hace partícipe al telespectador. Ver imágenes reales del lugar donde ha ocurrido un hecho y escuchar testimonios directos o el propio sonido ambiente hacen que la audiencia tenga acceso directo al hecho. La noticia es más accesible: la voz en off cuenta lo ocurrido pero es que además, se ven las consecuencias (González Requena, 1992: 95). La televisión ofrece mayor acceso y cercanía, mayor realidad y, por tanto, mayor credibilidad. $\mathrm{Y}$ esta tendencia la estamos viendo ya en el periodismo digital con la posibilidad de colgar videos. 


\section{El lenguaje televisivo en las noticias de Sociedad}

Esa cercanía que se produce entre las noticias televisadas y la audiencia es lo que obliga a contar las cosas de forma diferente (Oliva y Sitjá, 1999). Las noticias en la televisión no son discursos, en realidad son conversaciones, por eso el tono que se adopta es más familiar, teniendo en cuenta, además, el contexto en el que se ve y se consume televisión. El lenguaje audiovisual ha de ser claro y directo.

Valgan estos ejemplos para verlo rápidamente:

\begin{tabular}{|l|l|}
\hline \multicolumn{1}{|c|}{ PRENSA } & \multicolumn{1}{|c|}{ TV } \\
\hline $\begin{array}{l}\text { Los ciudadanos acuden a } \\
\text { votar a primeras horas de la } \\
\text { mañana }\end{array}$ & Los ciudadanos votan pronto. \\
\hline $\begin{array}{l}\text { España tiene previsto enviar } \\
\text { en fechas inmediatas un } \\
\text { contingente de tropas de } \\
\text { cerca de } 600 \text { hombres }\end{array}$ & $\begin{array}{l}\text { España enviará próximamente } \\
600 \text { soldados }\end{array}$ \\
\hline $\begin{array}{l}\text { Un niño ha muerto y dos } \\
\text { mujeres han resultado } \\
\text { heridas esta noche en un } \\
\text { incendio en Soria. }\end{array}$ & $\begin{array}{l}\text { En Soria, esta noche, ha muerto } \\
\text { unaño en un incendio y su } \\
\text { hadre yna vecina están } \\
\text { heridas. }\end{array}$ \\
\hline $\begin{array}{l}\text { El pillaje lo han } \\
\text { protagonizado las capas } \\
\text { sociales menos favorecidas. }\end{array}$ & $\begin{array}{l}\text { Los más pobres han saqueado } \\
\text { las tiendas. }\end{array}$ \\
\hline
\end{tabular}

El lenguaje de prensa está escrito para la vista y el audiovisual para el oído. En televisión no se escribe, se cuenta, por eso el texto ha de sonar natural. Este estilo, propio de la tv, es fácil de aprender, pero exige una técnica y un esfuerzo (Hartley, 2000: 47). Las noticias en televisión son una lucha contra el tiempo, en un minuto hay que explicar muchas cosas. Nadie habla de la misma forma que escribe, ni 
escribe de la misma forma que habla. Se trata de leer en voz alta aquello que se escribe y, además, que suene natural.

Para conseguir esa cercanía con la audiencia, hay que captar su atención en el mismo momento que se anuncia el titular. Los titulares en prensa son más descriptivos; en televisión, más breves e impactantes, juegan con el sentimentalismo para acercarse a los telespectadores.

\section{Conclusiones}

- De cada 10 noticias de Sociedad que recoge un periódico, 4 son contadas en televisión. Y el criterio de esa selección va en función de las imágenes y del morbo que la historia pueda despertar. En prensa se abordan con más profundidad pero en televisión son más reales, más creíbles porque además se ven.

- $\quad$ El tratamiento informativo de las noticias de Sociedad es diferente en prensa escrita y en televisión. En este último medio, las noticias se reportajean. Las noticias no informan, cuentan una historia. Y qué mejor, para contar una historia, que personalizarla, es decir, poner cara y nombre a la noticia: por ejemplo, para explicar la nueva Ley de Reforma Laboral de 2002, el periodista entabla una conversación con un jubilado para contar cómo le afecta y después explicar los aspectos más destacados de la ley.

- Las noticias de sociedad no son sólo sucesos. El asesinato de una mujer a manos de su ex pareja no es un suceso aislado, es una realidad de nuestra sociedad. No todos los que conducen se matan en las carreteras. El periodista tiene que explicar los porqués. $Y$ el morbo hace un flaco favor a este objetivo. Se hace necesario, por el bien del periodismo, esa concepción que, por otro lado, viene marcada por los gustos de la audiencia. Pero debemos ser constructivos y, los primeros, los editores de los informativos a la hora de confeccionar la escaleta: son 
ellos los que deben dar importancia a la sección de Sociedad. Al fin y al cabo, se trata de reflejarnos a nosotros mismos como ciudadanos. Y la inmensa mayoría no es tan mala como parece en los telediarios.

\section{Bibliografía}

AGUILERA, M. de (1985): El Telediario. Un proceso informativo . Mitre. Barcelona.

BARROSO, J. (1992): Proceso de la información de actualidad en televisión. Intituto de Radio y Televisión. Madrid.

CONTRERAS, J. M. y PALACIO, Manuel (2001): La programación de televisión. Editorial Síntesis. Madrid.

COLOMO, F. (1976): Televisión: la realidad como espectáculo. Gustavo Pili. Barcelona.

GARCÍ A NEBREDA, B., MENOR, J., y PERALES, A. (1985): Telediarios y producción de la realidad. Instituto de RTVE. Madrid.

GONZÁLEZ REQUENA, J. (1992): El discurso televisivo, espectáculo de la postmodernidad. Cátedra. Madrid.

HARTLEY, J. (2000): Los usos de la televisión. Ediciones Paidós I bérica. Barcelona.

OLIVA, L. y SITJÁ, X. (1999): Las noticias en televisión, un manual de técnicas de redacción y producción de noticias. Instituto de RTVE. Madrid.

ROGLÁN, M. y EQUIZA, P.: Televisión y lenguaje: Aportaciones para la configuración de un nuevo lenguaje periodístico. Ariel. Barcelona. 